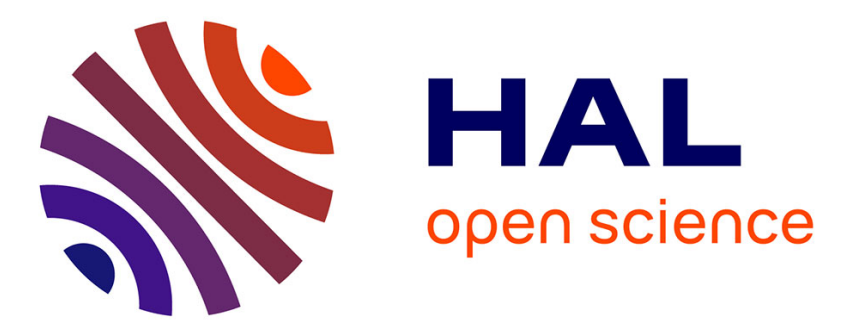

\title{
Experimental analysis of fuel from fish processing industry waste in a diesel engine
}

\author{
Edwin Geo Varuvel, Nadia Mrad, Fethi Aloui, Mohand Tazerout
}

\section{To cite this version:}

Edwin Geo Varuvel, Nadia Mrad, Fethi Aloui, Mohand Tazerout. Experimental analysis of fuel from fish processing industry waste in a diesel engine. Clean Technologies and Environmental Policy, 2016, 19 (4), pp.1099-1108. 10.1007/s10098-016-1303-z . hal-01525727

\section{HAL Id: hal-01525727 \\ https://hal.science/hal-01525727}

Submitted on 28 Jun 2021

HAL is a multi-disciplinary open access archive for the deposit and dissemination of scientific research documents, whether they are published or not. The documents may come from teaching and research institutions in France or abroad, or from public or private research centers.
L'archive ouverte pluridisciplinaire HAL, est destinée au dépôt et à la diffusion de documents scientifiques de niveau recherche, publiés ou non, émanant des établissements d'enseignement et de recherche français ou étrangers, des laboratoires publics ou privés. 


\title{
Experimental analysis of fuel from fish processing industry waste in a diesel engine
}

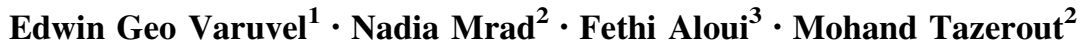

\begin{abstract}
In the present work, biofuel derived from industrial fish processing industry waste is used in diesel engines to study its suitability. Biofuel from industry fish waste is produced through catalytic cracking, and its quality has been improved through distillation. A single cylinder $4.5 \mathrm{~kW}$ at $1500 \mathrm{rpm}$ was used to find the suitability of biofuel and undistilled biofuel in diesel engine. Experimental results show that the brake thermal efficiency of biofuel and undistilled biofuel is similar. Brake thermal efficiency for diesel, undistilled biofuel and biofuel is $29.98,32.12$ and $32.4 \%$, respectively, at $80 \%$ load. Carbon monoxide, unburnt hydrocarbons, particulate matter and oxides of nitrogen emissions increase with undistilled biofuel compared to biofuel. There is a small reduction in carbon dioxide emission with undistilled biofuel compared to biofuel. Even though the cylinder pressure is high with undistilled biofuel, the intensity of premixed combustion is lower than distilled biofuel. The ignition delay and combustion duration increase with undistilled biofuel. Finally, it is concluded that the fuel derived from fish processing
\end{abstract}

Edwin Geo Varuvel

vedwingeo@gmail.com

1 Department of Automobile Engineering, SRM University, Kattankulathur 603203, India

2 Département Systèmes Energétiques et Environnement (DSEE), GEPEA, CNRS-UMR 6144, École des Mines de Nantes, 4 rue Alfred Kastler, BP20722, 44307 Nantes Cedex 03, France

3 LAMIH CNRS UMR 8201, University of Valenciennes and Hainault-Cambresis (UVHC), Campus Mont Houy, 59300, 59313 Valenciennes Cedex 9, France industry waste can be used as a fuel for diesel engine after distillation.

Keywords Fish processing industry waste $\cdot$ Catalytic cracking · Biofuel - Distillation and diesel engine

\section{Introduction}

Transportation is the main reason why Europe depends so heavily on crude oil. Crude oil is imported from foreign countries majorly from Persian Gulf (this region provides one-fourth of the world's current consumption of oil and nearly two-thirds of the world's oil reserves). Due to supply depletion and distribution instability, reliance on fossil fuel is inevitable. Oil is a finite resource, which means that its supply is limited and cannot be reproduced. It took millions of years for these oil reserves to accumulate, and it has been used up in less than two hundred years. It is estimated that the current known reserves of oil on earth will only be able to supply total world demand for the next 40 years. When these reserves are completely exhausted, the total world will have to use alternative fuel sources. Most of these alternative fuels are renewable which means that their supply is infinite and that they can be produced and supplied forever without any fear of depletion (Nigam and Singh 2011; No 2011; Baños et al. 2011). In addition, these fuels can be produced within the country itself. Hence, there is no need to depend on foreign countries for fuel supply. Currently, throughout the world, many researchers are working to find the alternative renewable sources of fuel for their countries (Sobrino et al. 2010; Ajanovic 2008; Ediger and Kentel 1999; Misra and Murthy 2011; Jayed et al. 2011).

There are several environmental issues generated due to fossil fuel use in internal combustion engines. The main 
pollutants from the engines are particulate matter, oxides of nitrogen, sulfur dioxide, carbon monoxide (CO) and carbon dioxide $\left(\mathrm{CO}_{2}\right)$ emissions (Lif et al. 2007; Jerry et al. 1996; Krishnamurthy et al. 2007). Other than these common environmental issues, it degrades the environment in other indirect ways too. Water pollution associated with gasoline includes marine oil spills, groundwater contamination from underground gasoline storage tanks and runoff resulting from fuel spills (Middleditch 1981; Meo et al. 2008; Rodríguez-Trigo et al. 2007). Biofuels can replace the most toxic parts of gasoline with fuels that quickly biodegrade in water, reducing the threat that gasoline poses to waterways and groundwater. Spills or leaks of biofuels do not constitute an environmental hazard.

Rapid increase in volume and types of biomass waste as a result of intensive industrialization in the wake of population growth and improved living standards is becoming a burgeoning problem as rotten biomass waste emits methane and leachate, and open burning by the humans to clear the lands generates $\mathrm{CO}_{2}$ and other local pollutants (Zhang et al. 2008; Dolk et al. 1998). Hence, improper management of biomass waste is contributing toward climate change, water and soil contamination, and localized air pollution. Furthermore, this waste is of high value with respect to material and energy recovery. Almost half the landfills in the Europe are close to capacity and are expected to close in the near future. To make matters worse, the rate at which the production of waste continues to increase is alarming. Disposal costs increase as available landfill space decreases. In addition, some segments of the agricultural and products from industries produce huge amounts of waste each year. Much of the waste is made of lignocellulosic material that can be converted to biofuels (Canakci 2007; Encinar et al. 2011; Gürü et al. 2010). This form of recycling could help relieve our exponentially growing waste problem while at the same time replacing a portion of our fossil fuel usage. With the global campaign to combat climate change, countries are now looking for alternative sources of energy to minimize greenhouse gas (GHG) emissions. Aside from being carbon neutral, the use of biomass for energy reduces dependency on the consumption of fossil fuel, hence contributing to energy security and climate change mitigation.

From the above, our dependence on petroleum for fueling the transportation sector threatens our energy security, affects environment and weakens economy. Several compelling issues drive a national effort to develop and improve technology to make biofuels. Developing the technology to produce and use biofuels will create transportation fuel options that can positively impact these issues and establish safe, clean and sustainable alternatives to fossil fuels. There are several processes to derive the energy from biomass waste (Demirbas 2008; Ito et al.
2012; Liu et al. 2011; Shakinaz et al. 2010; Hilten et al. 2010; Munasinghe and Khanal 2010; Zhang 2010). The two important conversion processes are thermochemical and biochemical.

The main objectives of the present work are to identify the biomass source and assess environmentally sound technologies for converting and upgrading lignocellulosic biomass into biofuel and also to find the suitability of biofuel in internal combustion engines. In this regard, the waste from fish processing industry has been identified as biomass waste to derive biofuel. Biofuel from fish processing industry waste through pyrolysis has a very high acid value of $131.1 \mathrm{mg}_{\mathrm{KOH}} / \mathrm{g}_{\mathrm{oil}}$ by Wiggers et al. (2009). Hence, pyrolysis with the presence of catalyst (catalytic cracking) was selected to valorize the biofuel from fish processing industry waste. The biofuel was upgraded through distillation process to optimize its quality on par with diesel fuel. Finally, the upgraded biofuel (distilled) was tested in diesel engine and the performance, emission and combustion characteristics were compared with undistilled biofuel and diesel fuel.

\section{Biofuel preparation and analysis}

\section{Preparation of biofuel}

The feedstock used in this work is a fish processing industry waste obtained from SIRH group specialized in vegetable, animal and marine oils located in north of France. This waste is the residue of marine oil treatment which is brown in color and was used without any special purification treatment. The typical fatty acid composition has been analyzed by gas chromatography analysis (GC/ FID). The saturated acids C14:0, C16:0 and C18:0 were identified. The major fatty acids found are the unsaturated acids $\mathrm{C} 18: 1$ and $\mathrm{C} 18: 2$ responsible for 45.6 and 20.6\%, respectively, of the total composition. The important properties of fish processing industry waste are given in Table 1.

To prepare the biofuel, catalytic cracking experiments were carried out at temperatures ranging from 350 to $480{ }^{\circ} \mathrm{C}$ with a slow heating rate of $2-3{ }^{\circ} \mathrm{C} / \mathrm{min}$ using a laboratory-scale reactor. The fat was introduced in the reactor and then heated by an external electric resistance. The catalyst was placed just above the fat on a bed with small holes. When the temperature inside the reactor reached $350{ }^{\circ} \mathrm{C}$, the reaction started. The generated vapor was passed directly over the catalyst surface before leaving through the top of the reactor. Then, it enters in a watercooled, counter flow, heat exchange, which was kept at $15{ }^{\circ} \mathrm{C}$. As a result, three fractions of liquids were collected in the flask: The first is the pyrolysis water, and the second 
Table 1 Main properties of the waste fish fat

\begin{tabular}{ll}
\hline Properties & Waste fish fat \\
\hline Visual aspect & Liquid at $60{ }^{\circ} \mathrm{C}$, brown color, typical smell \\
Water content $(\%)$ & $<0.05 \%$ \\
Flash point $\left({ }^{\circ} \mathrm{C}\right)$ & 318 \\
High heating value $(\mathrm{kJ} / \mathrm{kg})$ & 39,000 \\
Kinematic viscosity $\left(\mathrm{mm}^{2} / \mathrm{s}\right)$ & 27 \\
Density $\left(\mathrm{kg} / \mathrm{m}^{3}\right)$ & 0.893 \\
Composition of fatty acids $(\%)$ & \\
Mysteric & 1.05 \\
Palmitoleic & 5.00 \\
Palmitic & 16.00 \\
Stearic & 10.50 \\
Oleic & 45.60 \\
Linoleic & 20.60 \\
\hline
\end{tabular}

liquid fraction recovered until the temperature reached $400{ }^{\circ} \mathrm{C}$. The last fraction is the bio-oil recovered from 400 to $480{ }^{\circ} \mathrm{C}$. After acidity analysis, it was found that the second fraction was so acidic (acid value equal to $20 \mathrm{mg}_{\mathrm{KOH}} / \mathrm{g}$ ) compared to the third one (acid value equal to $0.8 \mathrm{mg}_{\mathrm{KOH}} / \mathrm{g}$ ). For this, the main interest is focused on third fraction which is called biofuel.

\section{Distillation of biofuel}

The flashpoint of biofuel is very low $\left(27^{\circ} \mathrm{C}\right)$ compared to the diesel fuel $\left(56{ }^{\circ} \mathrm{C}\right)$. The volatile compounds reflect low flashpoint of biofuel. Hence, distillation was performed to extract the most volatile hydrocarbons from biofuel. The distillation was conducted at temperatures between 130 and $140{ }^{\circ} \mathrm{C}$, and the mass recovered from the volatile hydrocarbon represents $5 \%$ of the total mass of biofuel. After gas chromatography-mass spectrometry (GC/MS) analysis, it was found that the organic compounds present in the biofuel were divided into eight classes: alkene, alkane, cycloalkane, acetone, aromatic compound, chlorinated compound, phenol and ester. The major components were alkene, alkane and acetone.

\section{Analysis of biofuel}

The flashpoint was measured by NPM 440 model (PENSKY-MARTENS). The acid value was determined by titration with $\mathrm{KOH} / \mathrm{C}_{2} \mathrm{H}_{5} \mathrm{OH}$ solution using phenolphthalein as an indicator. The density of the bio-oil was estimated with a pycnometer. The gross heating value was measured using an oxygen bomb calorimeter (model 6200, Parr Instruments Company). To identify the dynamic viscosity, a SV 10 Fibro viscometer was used. The elemental compositions of the main organic elements $(\mathrm{C}, \mathrm{O}, \mathrm{H}, \mathrm{S}$ and $\mathrm{N}$ ) were determined using an Elemental Analyzer (Flash
EA 1112, CE Instruments). In order to estimate the chemical compounds of the biofuel, a GC/MS analysis was carried out. For this purpose, a Perkin-Elmer TurboMass Gold Mass Spectrometer coupled with a gas chromatograph CLARUS 500 was used. The column was SBLTM-5 ms capillary type, $30 \mathrm{~m}$ in length and $0.25 \mathrm{~mm}$ in internal diameter. The properties of biofuel UD (undistilled biofuel), biofuel and standard diesel fuel are given in Table 2.

\section{Experimental setup}

\section{Performance instrumentation}

A single-cylinder, four-stroke, air-cooled, direct injection, and constant speed diesel engine developing power output of $4.5 \mathrm{~kW}$ was used for this work. Test engine specifications are given in Table 3. The engine was mounted on a fixed table and coupled with an eddy current dynamometer that converts mechanical energy generated by the engine power directly to the network. The flow of intake air was measured by a differential pressure transmitter, type LPX 5481. For temperature measurements, the test engine was equipped with a series of thermocouples type K. Ambient temperature was measured by an active transmitter for humidity and temperature, type HD 2012 TC/150. The fuel flow was measured using a Coriolis mass flow meter. Torque measurement was made using a force sensor used in tension and compression of the FN3148 series. It has an accuracy of $0.05 \%$ of range of the measure. The CI engine was run for $3 \mathrm{~h}$ continuously to conduct one set of load test (five loading conditions). After attaining the steady state, the readings were taken. Inline measurements were taken for air flow, fuel flow, temperatures and torque measurements. The tests 
Table 2 Properties of undistilled biofuel (biofuel UD), biofuel and diesel

\begin{tabular}{lllll}
\hline Properties & Unit & Undistilled biofuel & Biofuel & Diesel fuel \\
\hline Flash point & ${ }^{\circ} \mathrm{C}$ & 27 & 57 & 56 \\
Acidity & $\mathrm{mg}_{\mathrm{KOH}} / \mathrm{g}$ & 0.2 & 0.8 & - \\
$\mathrm{HHV}$ & $\mathrm{MJ} / \mathrm{kg}$ & 45.25 & 45.10 & 45.71 \\
$\mathrm{LHV}$ & $\mathrm{MJ} / \mathrm{kg}$ & 42.87 & 42.74 & 43.36 \\
Dynamic viscosity at $20{ }^{\circ} \mathrm{C}$ & $\mathrm{Ns} / \mathrm{m}^{2}$ & 2.11 & 2.32 & 2.52 \\
Density at $20{ }^{\circ} \mathrm{C}$ & $\mathrm{kg} / \mathrm{m}^{3}$ & 818 & 825 & 830 \\
Kinematic viscosity at $20{ }^{\circ} \mathrm{C}$ & $\mathrm{mm}^{2} / \mathrm{s}$ & 1.72 & 1.7 & 2 \\
Auto-ignition temperature & ${ }^{\circ} \mathrm{C}$ & - & 230 & 220 \\
Cetane index & & - & 57 & 52 \\
Cloud point & ${ }^{\circ} \mathrm{C}$ & 9 & 9 & - \\
Pour point & ${ }^{\circ} \mathrm{C}$ & -5 & -5 & - \\
Cold filter plugging point & ${ }^{\circ} \mathrm{C}$ & 14 & 14 & - \\
\hline
\end{tabular}

Table 3 Specifications of test engine

\begin{tabular}{ll}
\hline Make & Lister petter \\
\hline No of cylinders & One \\
Type of cooling & Air cooled \\
Bore $\times$ stroke & $95.5 \times 88.94 \mathrm{~mm}$ \\
Length of connecting rod & $165.3 \mathrm{~mm}$ \\
Displacement & $630 \mathrm{~cm}^{3}$ \\
Fuel injection timing & $20^{\circ} \mathrm{bTDC}$ \\
Fuel injection pressure & $250 \mathrm{bar}$ \\
Compression ratio & $18: 1$ \\
Rated power & $4.5 \mathrm{~kW} @ 1500 \mathrm{rpm}$ \\
\hline
\end{tabular}

were repeated for five times to check the repeatability of the readings.

\section{Emission instrumentation}

For measuring emissions, a bay of analysis (Crystal COSMA 500) placed on the line of engine exhaust gas was used to analyze the main pollutant gases. Emissions of hydrocarbons (HC) were measured by FID flame ionization using a heated hydrocarbon analyzer (model GRAPHITE $52 \mathrm{M}$ ); emissions of nitric oxide (NO) and nitrogen oxides (NOx) were measured via a chemiluminescence nitrogen oxide analyzer TOPAZE $32 \mathrm{M}$. Emissions of carbon monoxide $(\mathrm{CO})$, carbon dioxide $\left(\mathrm{CO}_{2}\right)$ and oxygen $\left(\mathrm{O}_{2}\right)$ were measured by absorption of infrared radiation using a 2 M MIR analyzer. Part of the exhaust gas was bypassed, and measurements were taken for emissions parameters like $\mathrm{NOx}, \mathrm{UHC}, \mathrm{CO}$ and $\mathrm{CO}_{2}$. Each sampling was conducted for 10 -min duration. Particulate emissions were measured using a dust analyzer in real time (TEOM model
1105), for measurement and continuous weighing of the mass concentration of particulate exhaust.

\section{Combustion instrumentation}

A control system was installed to measure high-frequency signal, which mainly concerns the cylinder pressure, fuel injection pressure and also the angular position of the crankshaft. The pressure in the cylinder was measured at a frequency of $90 \mathrm{kHz}$ using a piezoelectric pressure sensor, water-cooled, type AVL QH32D. The injection pressure was measured by a piezoelectric pressure transducer, type AVL QH33D, located in between the injection pump and the fuel injector. The angular position of the crankshaft was measured by an encoder, type AVL 364C, placed on the flywheel. Cylinder pressure was recorded for 100 cycles; then, mean was taken for calculating heat release and other combustion parameters. The schematic of test engine setup is shown in Fig. 1.

\section{Results and discussion}

\section{Performance parameters}

\section{Brake thermal efficiency}

Figure 2 compares the brake thermal efficiency of diesel, biofuel UD (undistilled biofuel) and biofuel with brake power. It is observed that the brake thermal efficiency of biofuel is higher compared to diesel fuel and biofuel UD at various load conditions. There is a slight decrease in brake thermal efficiency with all test fuels at full load. The brake thermal efficiency is about $30.8 \%$ with biofuel, $28.69 \%$ with diesel and $30.5 \%$ with biofuel UD at maximum load. It is maximum at $80 \%$ load. The brake thermal efficiency 
Fig. 1 Schematic diagram of the engine setup. (1) Test engine, (2) biofuel tank, (3) diesel fuel tank, (4) exhaust gas analyzer, (5) eddy current dynamometer, (6) particulate matter analyzer, (7) lowfrequency data acquisition system, (8) charge amplifier, (9) high-frequency data acquisition system, (10) crank angle encoder/speed sensor, (11) injection pressure signal and (12) cylinder pressure signal
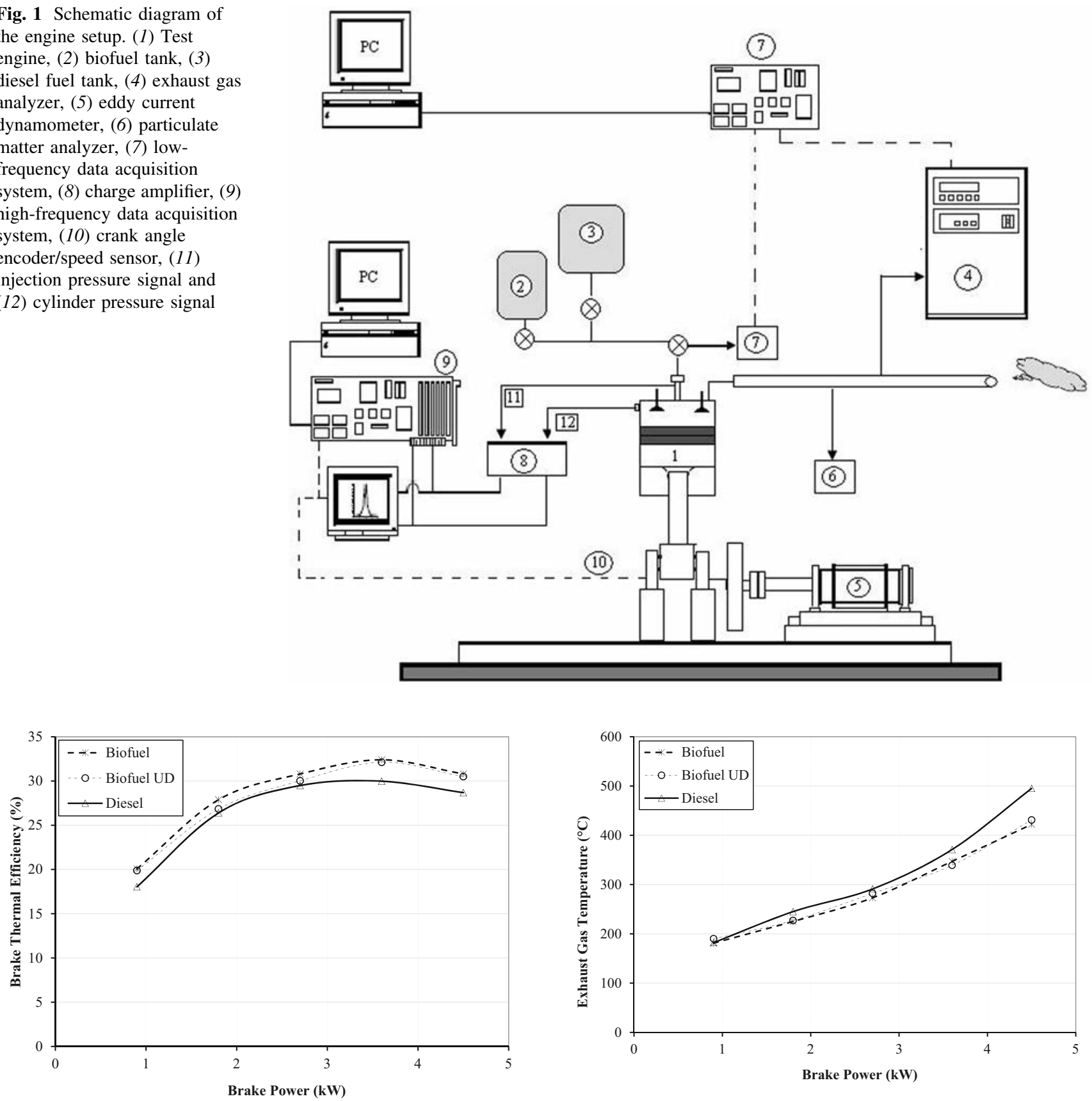

Fig. 2 Variation of brake thermal efficiency with brake power

for biofuel, diesel and biofuel UD at $80 \%$ load is 32.4, 29.98 and $32.12 \%$, respectively. The decrease in brake thermal efficiency is lesser with biofuel UD compared to biofuel at higher loads. This is due to better mixture formation as a result of high volatility of hydrocarbons leading to better combustion. The brake thermal efficiency mainly depends on amount of energy released during the initial phase of combustion (premixed combustion). This can be easily observed from heat release rate diagram

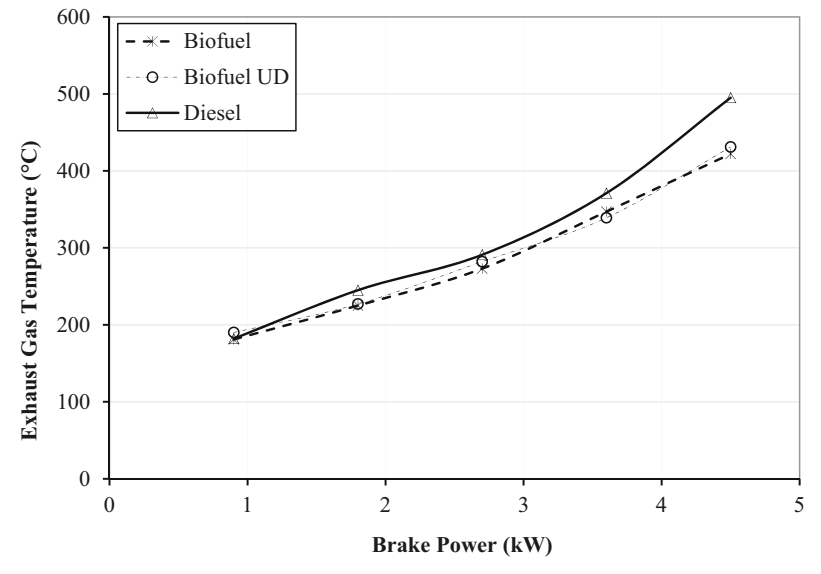

Fig. 3 Variation of exhaust gas temperature with brake power

(Fig. 12). It shows that the premixed combustion is very sharp with biofuel and biofuel UD compared to diesel.

\section{Exhaust gas temperature}

Figure 3 shows the variation of exhaust gas temperature for different test fuels with brake power.

The exhaust gas temperature is lower with biofuel and higher with diesel. It is 422,495 and $431{ }^{\circ} \mathrm{C}$ for biofuel, diesel and biofuel UD at maximum load condition, respectively. Lower viscosity and good volatility of biofuel 
and biofuel UD lead to better mixture formation, and hence, higher premixed combustion phase makes the heat release shorter. Also, lower ignition delay starts the combustion earlier and shortens the combustion duration results in lower exhaust gas temperature compared to diesel. Although combustion starts earlier with biofuel UD due to lower ignition delay, the intensity of premixed combustion is not wide compared to biofuel which is evident from heat release diagram. The amount of fuel prepared during the ignition delay is very low due to high volatile hydrocarbons present in the biofuel UD. Hence, more amount of fuel is burnt during diffusion combustion phase, which leads to higher exhaust gas temperature with biofuel UD compared to biofuel.

\section{Emission parameters}

\section{Oxides of nitrogen emissions (NOx)}

The variation of oxides of nitrogen (NOx) levels for biofuel, biofuel UD and diesel with brake power is shown in Fig. 4. The formation of NOx is mainly due to the reaction between the nitrogen and oxygen at higher combustion temperature. The combustion temperature mainly depends on the initial phase of combustion (premixed combustion). NOx increases from 20 to $80 \%$ load and reduces slightly at maximum load with all test fuels. As the load increases, the combustion temperature increases due to that higher NOx. As seen in Fig. 4, NOx emissions with biofuel UD are high compared to diesel and biofuel at all loads. NOx emissions for biofuel UD, diesel and biofuel are 994, 780 and 857 ppm, respectively, at full load and 1001, 852 and 917 ppm, respectively, at maximum efficiency point $(80 \%$ load). Higher NOx with biofuel UD is due to lower flashpoint and highly volatile hydrocarbons of fuel which initiates the strong premixed combustion. Heat release shows that the premixed combustion is very sharp with biofuel

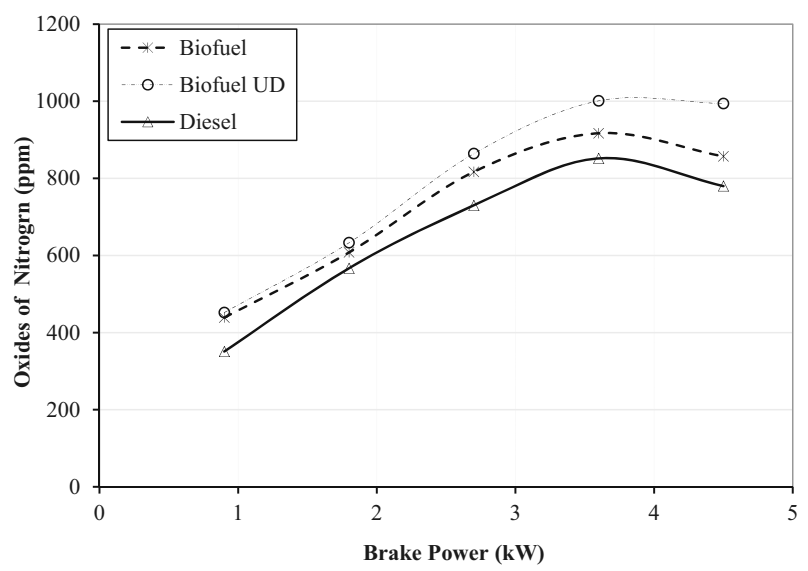

Fig. 4 Variation of oxides of nitrogen with brake power
UD than diesel and biofuel. Hence, higher NOx is with biofuel UD than diesel and biofuel.

\section{Unburned hydrocarbon emissions (UHC)}

Figure 5 shows the variation of unburned hydrocarbons with brake power. UHC in the exhaust shows the unutilized energy during combustion process. This is due to the fuel droplets unable to reach the ignition temperature, leading to incomplete combustion. It is also due to insufficient quantity of oxygen to oxidize the fuel present in the combustion chamber. It is clearly shown that the UHC is lower with biofuel compared to diesel and biofuel UD. The UHC emission for biofuel, diesel and biofuel UD at maximum load is 502, 575 and 518 ppm, respectively. Lower UHC for biofuel is mainly due to the early start and end of combustion of biofuel. The increase in UHC emission with biofuel UD is mainly due to more fuel being burned at diffusion part of combustion though the ignition starts earlier.

\section{Carbon monoxide emission (CO)}

The variation of carbon monoxide for biofuel, diesel and biofuel UD with brake power is shown in Fig. 6. At maximum load, the $\mathrm{CO}$ emission with biofuel and biofuel UD is 0.39 and $0.41 \%$, respectively, whereas it is $0.59 \%$ with diesel. CO emission reduces with biofuel UD, and it is further reduced with biofuel. Due to the good spray characteristics as a result of low viscosity of biofuel and biofuel UD, all the fuel droplets are mixed with air at the end part of the compression stroke, leading to better oxidation reaction of the fuel which results in complete combustion. Also, biofuel and biofuel UD itself have higher oxygen content tending to increase the oxidation process. The slight increase in $\mathrm{CO}$ emission with biofuel UD is due to longer combustion duration compared to biofuel.

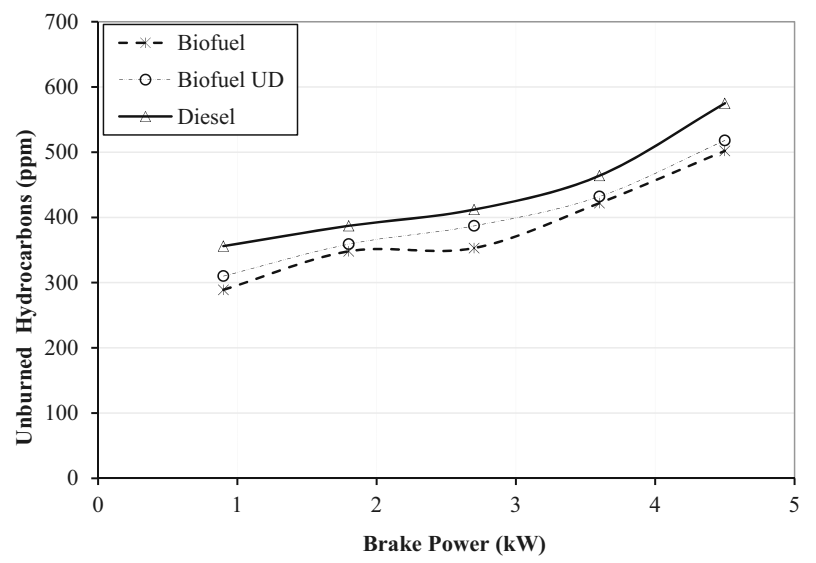

Fig. 5 Variation of unburned hydrocarbons with brake power 


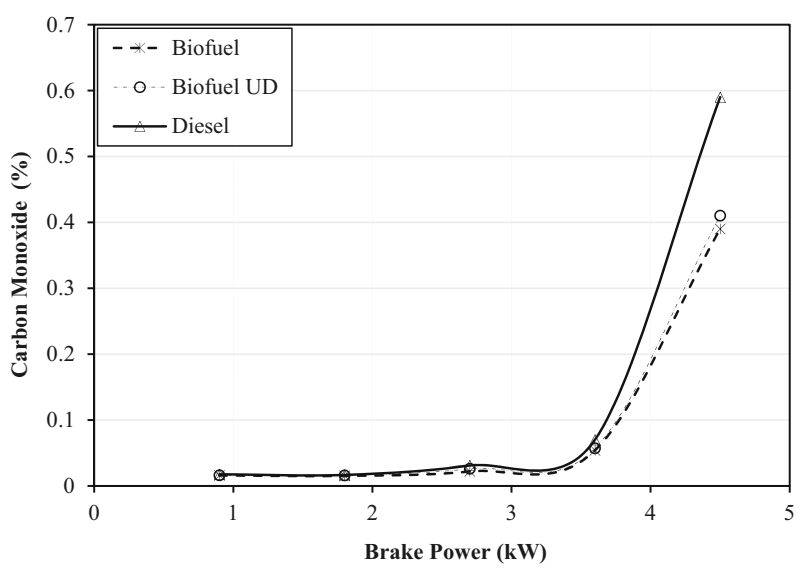

Fig. 6 Variation of carbon monoxide with brake power

\section{Carbon dioxide emission $\left(\mathrm{CO}_{2}\right)$}

Figure 7 shows the variation of carbon dioxide emission for different fuels with respect to brake power. $\mathrm{CO}_{2}$ present in the exhaust gas reflects the combustion efficiency. Combustion improved if $\mathrm{CO}_{2}$ is more in the exhaust. But, nowadays, the $\mathrm{CO}_{2}$ is a pollutant which is one of the gases for the formation of green house effect. $\mathrm{CO}_{2}$ emission at the rated power is about $9.74 \%$ with biofuel, $9.28 \%$ with biofuel UD and $9.15 \%$ with diesel. The increase in $\mathrm{CO}_{2}$ emission with biofuel is due to higher oxygen present in the molecular chain, leading to better combustion than diesel. Although the biofuel UD has higher oxygen concentration, the $\mathrm{CO}_{2}$ emission reduced marginally. This is mainly due to more fuel being burned in the later part of combustion which reduces the combustion efficiency.

\section{Oxygen $\left(\mathrm{O}_{2}\right)$}

The variation of oxygen percentage in the exhaust with brake power is shown in Fig. 8. The amount of oxygen

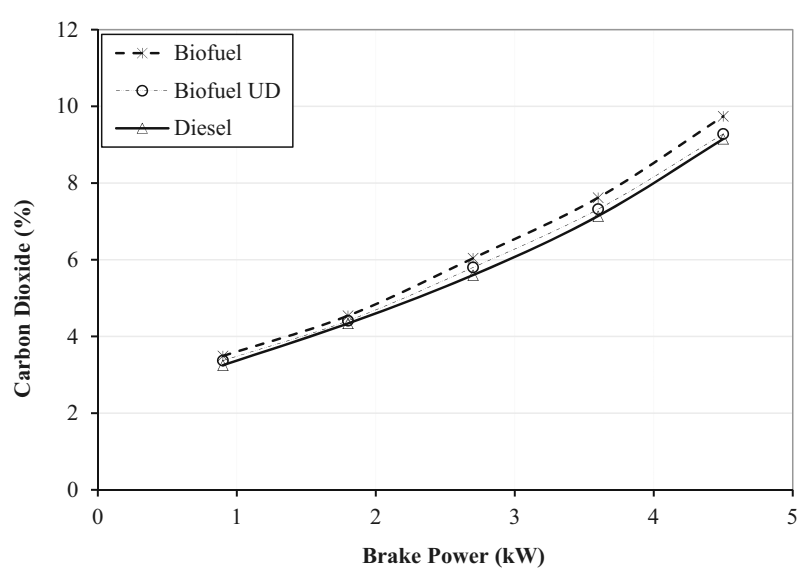

Fig. 7 Variation of carbon dioxide with brake power

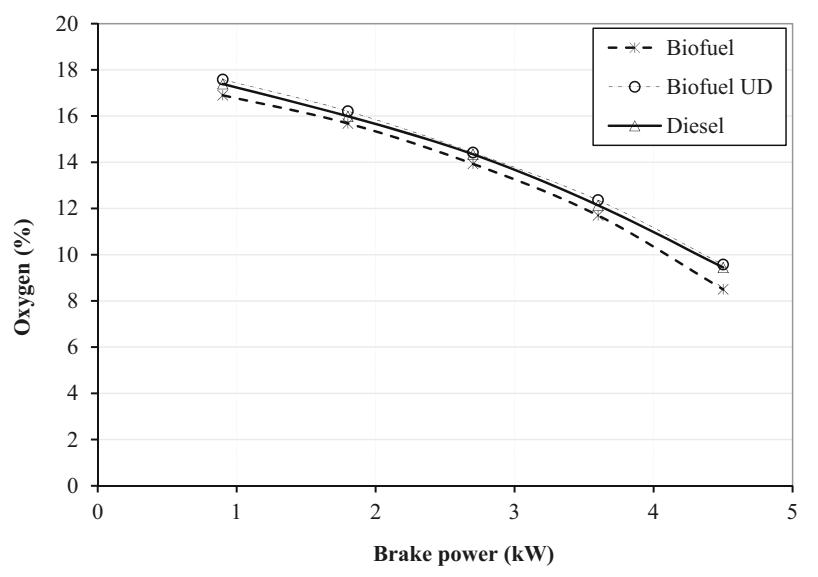

Fig. 8 Variation of oxygen with brake power

present in the exhaust indicates combustion is complete. As seen in the graph, the oxygen percentage is higher with biofuel UD and it is reduced with diesel and biofuel. The value of oxygen emission for biofuel, diesel and biofuel UD is $8.5,9.45$ and $9.57 \%$, respectively, at maximum load. Normally, oxygen present in the air reacts with fuel and excess oxygen leaves the combustion chamber during exhaust process. Biofuel UD has higher oxygen percentage $(5.42 \%)$ itself. Also, the combustion of biofuel UD is poor compared to biofuel which leads to higher oxygen percentage in the exhaust. Increase in the combustion process of biofuel leads to complete combustion which exhibits low oxygen emission in the exhaust.

\section{Particulate matter (PM)}

The results of particulate matter (PM) emissions of the three fuels are superimposed in Fig. 9. PM consists of a solid portion (carbon and ash), soluble organic fraction and sulfates. The SOF is hydrocarbons (mostly heavy hydrocarbons) that have condensed on the carbon particles. The solid

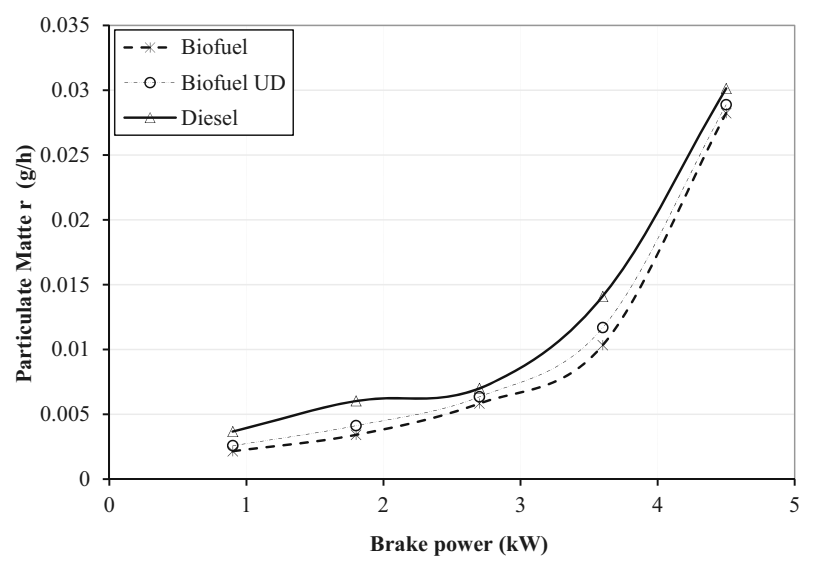

Fig. 9 Variation of particulate matter with brake power 
carbon portion and soluble organic fraction are formed by incomplete combustion of the fuel. This occurs at low airfuel ratios such as high load and during transient events when boost pressure is limited. High cylinder temperatures and the availability of oxygen increase the oxidization of the solid carbon particles and hydrocarbons to carbon monoxide and carbon dioxide. The highest particulate emission is obtained with diesel, and the value is about $0.03 \mathrm{~g} / \mathrm{h}$ at maximum load. The PM emission reduces with biofuel UD and biofuel; it is about 0.029 and $0.028 \mathrm{~g} / \mathrm{h}$ at maximum load, respectively. In general, the formation of PM is mainly dependant on the intensity of diffusion combustion. The intensity of diffusion combustion is higher with diesel followed by biofuel UD, which indicates that more quantity of fuel is burned during this combustion phase. It is very low with biofuel, and hence, more quantity of fuel has taken part in premixed combustion phase which reflects on the formation of NOx emissions. The PM for biofuel, diesel and biofuel UD at $80 \%$ load (maximum efficiency point) is 0.01 , 0.014 and $0.011 \mathrm{~g} / \mathrm{h}$, respectively, which is lower compared to maximum load condition.

\section{Combustion parameters}

\section{Cylinder peak pressure}

The variation of cylinder peak pressure with brake power is shown in Fig. 10. It is seen that biofuel UD has higher peak pressure than diesel and biofuel. However, the cylinder pressure for both biofuel UD and biofuel is almost same at all load conditions. It is about 90.1 bar with biofuel UD and 89.7 bar with biofuel at maximum load. The slight increase over biofuel is due to early ignition of biofuel UD and again, due to high volatile components of biofuel UD, leads to low flashpoint $\left(27^{\circ} \mathrm{C}\right)$. The cylinder peak pressure depends strongly on the initial combustion rate in diesel

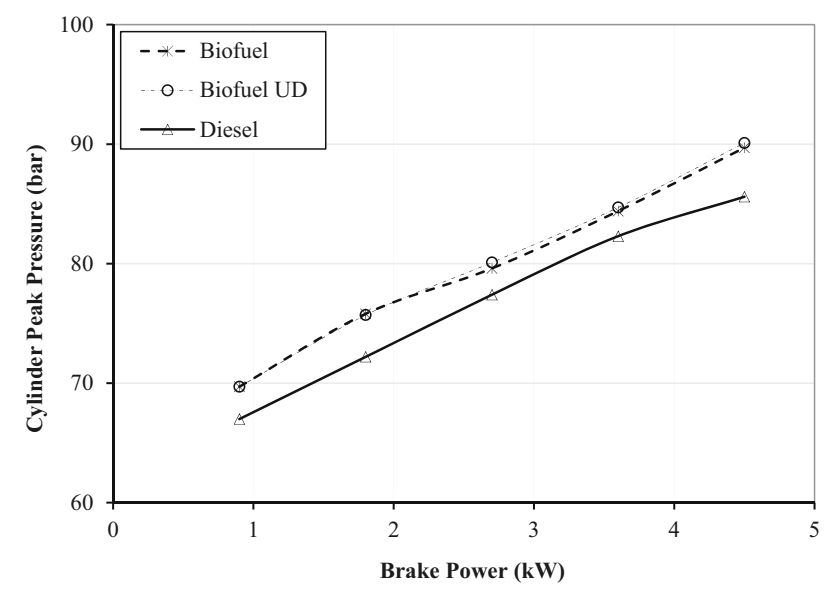

Fig. 10 Variation of cylinder peak pressure with brake power engines, which in turn depends on the amount of fuel taking part in the premixed combustion phase. Even though the ignition delay of biofuel UD is less, the premixed combustion rate is quite high with biofuel. The cylinder peak pressure for diesel is 85.6 bar at maximum load.

\section{Cylinder pressure}

Figure 11 clearly shows the variation of cylinder pressure with crank angle (CA) for biofuel, diesel and biofuel UD at maximum load. It can be seen that the maximum peak pressure is shifted by about $4.7^{\circ} \mathrm{CA}$ with biofuel UD and $4.3{ }^{\circ} \mathrm{CA}$ with biofuel after TDC. It is almost same for both biofuel and biofuel UD. But for diesel, it is about $6.1{ }^{\circ} \mathrm{CA}$ after TDC. The peak pressure of diesel is shifted due to longer ignition delay compared to biofuel, which may delay the start of combustion process. The ignition started earlier with biofuel UD, but intensity of premixed combustion is not wide compared to biofuel. Hence, for both diesel and biofuel UD, more energy is released in the later part of the expansion process.

\section{Rate of heat release}

The rate of heat release with crank angle for biofuel, diesel and biofuel UD at maximum load is shown in Fig. 12. The heat release rate is divided into two parts: the premixed combustion and diffusion combustion. Particular interest with combustion studies has been with premixed combustion. The maximum premixed heat release is the indication of higher brake thermal efficiency and NOx emissions. This can be realized from Figs. 2 and 4. Also, higher diffusion combustion is the indication of high particulate matter emission, which is evident from Fig. 9. The end of the premixed combustion has been defined as the dip after the premix spike, leading to the diffusion combustion. The

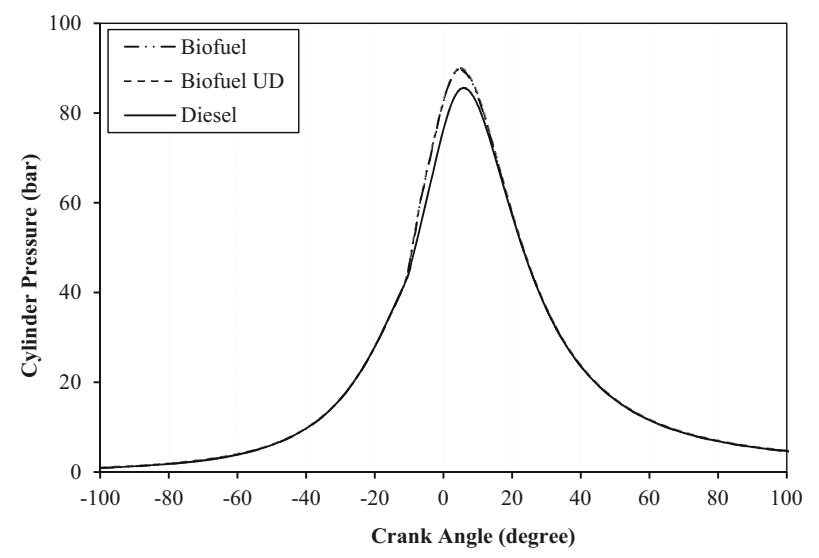

Fig. 11 Variation of cylinder pressure crank angle at maximum load 


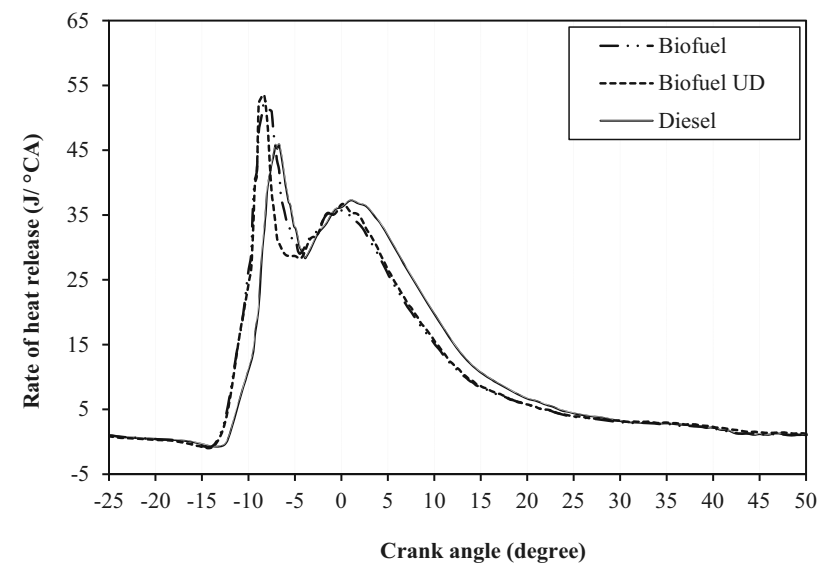

Fig. 12 Variation of heat release rate with crank angle at maximum load

intensity of premixed combustion is higher with biofuel, followed by biofuel UD and diesel, which shows the improved combustion with biofuel and biofuel UD compared to diesel. The occurrence of maximum premixed heat release rate is advanced by $8.3^{\circ} \mathrm{CA}$ before top dead center (TDC) with both biofuel UD and biofuel, and it is $7.1{ }^{\circ} \mathrm{CA}$ before TDC with diesel. The limited advance of premixed combustion may lead to improvement in expansion ratio. The diffusion burning, indicated by the second peak, is higher with diesel due to the burning of more quantity of fuel in the later part of combustion, which leads to lower thermal efficiency and higher exhaust gas temperature.

\section{Ignition delay}

The variation of ignition delay with brake power for biofuel, diesel and biofuel UD is shown in Fig. 13. Ignition delay is the time interval between the start of fuel injection and combustion measured by the sudden change in the slope of pressure crank angle diagram. Ignition delay provides an indication of the combustibility of the fuel

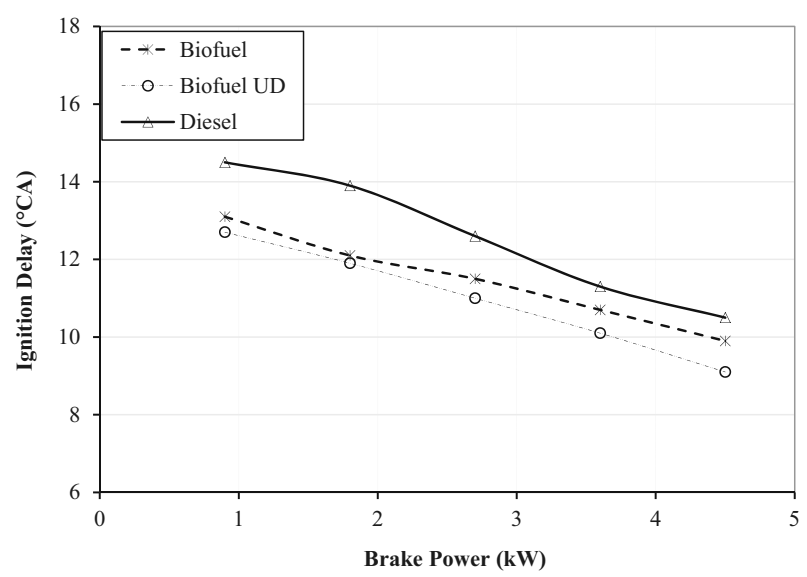

Fig. 13 Variation of ignition delay with brake power

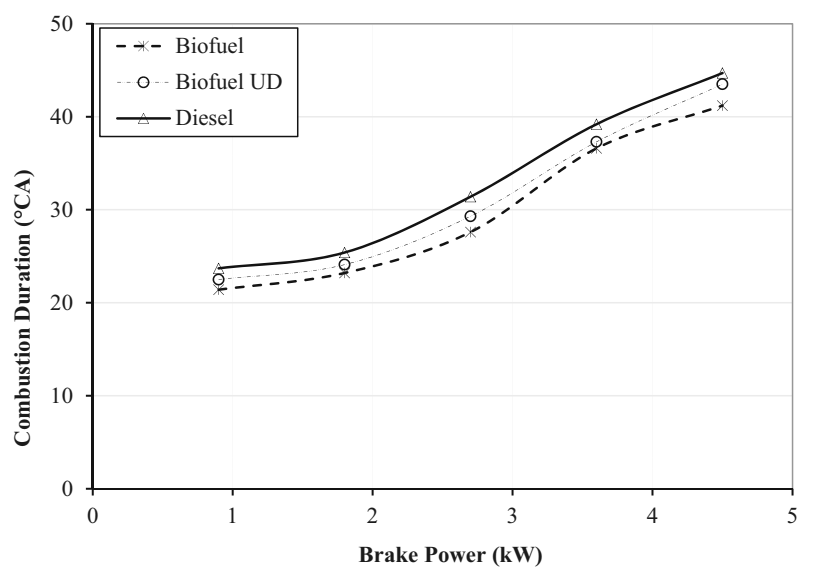

Fig. 14 Variation of combustion duration with brake power

injected and the mixing of the fuel and air. It is very high with diesel compared to biofuel UD and biofuel. The ignition delay for biofuel, diesel and biofuel UD at maximum load is 9.9, 10.5 and $9.1^{\circ} \mathrm{CA}$, respectively. The undistilled biofuel has more high volatile hydrocarbons, and hence, it converts quickly to vapor form and easily mixes with air. The flash point of biofuel UD is low $\left(27^{\circ} \mathrm{C}\right)$, which helps to start the combustion earlier.

\section{Combustion duration}

Figure 14 depicts the variation of combustion duration of the three fuels with brake power. Combustion duration is the time interval between the start of combustion to the $90 \%$ of fuel mass burnt. Combustion duration generally increases with increase in power output of the engine with all fuels due to increase in the quantity of fuel injected. It is marginally higher with diesel compared to biofuel and biofuel UD. Long combustion duration with diesel and biofuel UD indicates that too much fuel is injected to maintain the same power as the cylinder cools down during the expansion stroke, potentially causing incomplete combustion that leads to higher unburned hydrocarbons and particulate matter compared to biofuel. This is evident from Figs. 5 and 9. Combustion duration is $41.2{ }^{\circ} \mathrm{CA}$ with biofuel, $43.5^{\circ} \mathrm{CA}$ with biofuel UD and $44.7^{\circ} \mathrm{CA}$ with diesel. This decrease in combustion duration with biofuel is due to increase in intensity of premixed combustion rate as a result of better mixing of fuel and air, which is clear from the heat release rate curve as seen in Fig. 12.

\section{Conclusions}

Biofuel results in highest brake thermal efficiency of $32.4 \%$, whereas biofuel UD results in $32.12 \%$ at $80 \%$ load. There is not much difference in brake thermal efficiency 
with these fuels. Biofuel results in lower exhaust gas temperatures in comparison with biofuel UD on account of faster combustion. NOx emissions for the biofuel operation are 857 and 994 ppm with biofuel UD at full load. NOx emissions are higher with biofuel UD than biofuel because of highly volatile components making the initial combustion very fast. The $\mathrm{CO}$ and $\mathrm{HC}$ emissions are higher and $\mathrm{CO}_{2}$ emission is lower with biofuel UD compared to biofuel due to incomplete combustion. PM level of biofuel is lower as compared to biofuel UD. The PM level for biofuel is 0.028 and $0.029 \mathrm{~g} / \mathrm{h}$ for biofuel UD at full load. This is due to more amount of fuel being burned in the later part of combustion. There is not much change in cylinder peak pressure with biofuel and biofuel UD. It is 90.1 bar with biofuel UD and 89.7 bar with biofuel at full load. Heat release with biofuel UD indicates higher diffusion burning and lower intensity premixed burning rates as compared to biofuel. Ignition delay is lower with biofuel UD due to high volatile components, and combustion duration is long due to higher diffusion burning. At full load, the ignition delay and combustion duration are 9.1 and $43.5^{\circ} \mathrm{CA}$, respectively, and with biofuel UD compared to biofuel, it is 9.9 and $41.2{ }^{\circ} \mathrm{CA}$.

From the performance, emission and combustion analysis, the biofuel derived from fish processing industry waste can be considered as a viable substitute for diesel fuel compared to undistilled biofuel.

Acknowledgements GEPEA Laboratory and the Department of Energetic and Environmental Systems (DSEE) supported this research at the École des Mines de Nantes. These supports are gratefully acknowledged.

\section{References}

Ajanovic A (2008) On the economics of hydrogen from renewable energy sources as an alternative fuel in transport sector in Austria. Int J Hydrog Energy 33:4223-4234

Baños R, Manzano-Agugliaro F, Montoya FG, Gil C, Alcayde A, Gómez J (2011) Optimization methods applied to renewable and sustainable energy: a review. Renew Sustain Energy Rev 15:1753-1766

Canakci M (2007) The potential of restaurant waste lipids as biodiesel feedstocks. Bioresour Technol 98:183-190

Demirbas A (2008) Comparison of transesterification methods for production of biodiesel from vegetable oils and fats. Energy Convers Manag 49:125-130

Dolk H, Vrijheid M, Armstrong B, Abramsky L, Bianchi F, Garne E, Nelen V, Robert E, Scott JES, Stone D, Tenconi R (1998) Risk of congenital anomalies near hazardous-waste landfill sites in Europe: the EUROHAZCON study. The Lancet 352:423-427

Ediger VŞ, Kentel E (1999) Renewable energy potential as an alternative to fossil fuels in Turkey. Energy Convers Manag 40:743-755
Encinar JM, Sánchez N, Martínez G, García L (2011) Study of biodiesel production from animal fats with high free fatty acid content. Bioresour Technol 102:10907-10914

Gürü M, Koca A, Can Ö, Çınar C, Şahin F (2010) Biodiesel production from waste chicken fat based sources and evaluation with $\mathrm{Mg}$ based additive in a diesel engine. Renew Energy 35:637-643

Hilten R, Speir R, Kastner J, Das K (2010) Production of fuel from the catalytic cracking of pyrolyzed poultry DAF skimmings. J Anal Appl Pyrolysis 88:30-38

Ito T, Sakurai Y, Kakuta Y, Sugano M, Hirano K (2012) Biodiesel production from waste animal fats using pyrolysis method. Fuel Process Technol 94:47-52

Jayed MH, Masjuki HH, Kalam MA, Mahlia TMI, Husnawan M, Liaquat AM (2011) Prospects of dedicated biodiesel engine vehicles in Malaysia and Indonesia. Renew Sustain Energy Rev 15:220-235

Jerry C, Summers SV, Houtte DP (1996) Simultaneous control of particulate and NOx emissions from diesel engines. Appl Catal B 10:139-156

Krishnamurthy M, Carder DK, Thompson G, Gautam M (2007) Cost of lower NOx emissions: increased $\mathrm{CO}_{2}$ emissions from heavyduty diesel engines. Atmos Environ 41:666-675

Lif A, Skoglundh M, Gjirja S, Denbratt I (2007) Reduction of soot emissions from a direct injection diesel engine using water-indiesel emulsion and microemulsion fuels, SAE paper no. 2007-01-1076

Liu S, Wang Y, Oh J-H, Herring JL (2011) Fast biodiesel production from beef tallow with radio frequency heating. Renew Energy 36:1003-1007

Meo SA, Al-Drees AM, Meo IM, Al-Saadi MM, Azeem MA (2008) Lung function in subjects exposed to crude oil spill into sea water. Mar Pollut Bull 56:88-94

Middleditch BS (1981) Environmental effects of offshore oil pollution-the buccaneer gas and oil field study. Plenum Press, New-York

Misra RD, Murthy MS (2011) Jatropa-the future fuel of India. Renew Sustain Energy Rev 15:1350-1359

Munasinghe PC, Khanal SK (2010) Biomass-derived syngas fermentation into biofuels: opportunities and challenges. Bioresour Technol 101:5013-5022

Nigam PS, Singh A (2011) Production of liquid biofuels from renewable resources. Prog Energy Combust Sci 37:52-68

No S-Y (2011) Inedible vegetable oils and their derivatives for alternative diesel fuels in CI engines: a review. Renew Sustain Energy Rev 15:131-149

Rodríguez-Trigo G, Zock JP, Montes II (2007) Health effects of exposure to oil spills. Arch Bronconeumol 43:628-635

Shakinaz A, Sherbiny EI, Ahmed A, Refaat T, EL Shakinaz S (2010) Production of biodiesel using the microwave technique. J Adv Res 1:309-314

Sobrino FH, Monroy CR, Pérez JLH (2010) Critical analysis on hydrogen as an alternative to fossil fuels and biofuels for vehicles in Europe. Renew Sustain Energy Rev 14:772-780

Wiggers VR, Wisniewski A Jr, Madureira LAS, Chivanga Barros AA, Meier HF (2009) Biofuels from waste fish oil pyrolysis: continuous production in a pilot plant. Fuel 88:2135-2141

Zhang H, He P, Shao L (2008) Methane emissions from MSW landfill with sandy soil covers under leachate recirculation and subsurface irrigation. Atmos Environ 42:5579-5588

Zhang W (2010) Automotive fuels from biomass via gasification. Fuel Process Technol 91:866-876 